\title{
Az élelmiszertermelés relokalizációjának térbeli-társadalmi különbségei Magyarországon
}

\section{Socio-spatial differences in the relocalisation of food production in Hungary}

\author{
BENEDEK ZSÓFIA, BALÁZS BÁLINT
}

\begin{abstract}
BENEDEK Zsófia: tudományos segédmunkatárs, MTA Közgazdaság- és Regionális Tudományi Kutatóközpont, Közgazdaság-tudományi Intézet, Budapest; benedek.zsofia@krtk.mta.hu

BALÁZS Bálint: Environmental Social Science Research Group (ESSRG); tudományos segédmunkatárs, Szent István Egyetem, Mezőgazdaság- és Környezettudományi Kar, Természetvédelmi és Tájgazdálkodási Intézet, Gödöllő; balazs.balint@essrg.hu
\end{abstract}

KULCSSZAVAK: relokalizáció, helyi élelmiszerrendszer, rövid ellátási lánc, vidékfejlesztés, kvantitatív elemzés

ABSZTRAKT: Az elmúlt néhány évben a rövid élelmiszer-ellátási láncok gyors térnyerésének lehettünk tanúi világszerte. Ezzel párhuzamosan egyre erősebb az élelmiszer relokalizációjára vonatkozó politikai törekvés is. Jelen elemzésben a helyi élelmiszerrendszerek térbeli mintázatait és fejlődési lehetőségeit járjuk körül. A döntéshozatal támogatása érdekében kvantitatív vizsgálatot terveztünk, amely szokatlan megközelítés a helyi élelmiszerek relokalizációjának kutatásában. A vizsgálat alapját az élelmiszer-relokalizációs termelői index (ÉRTI) jelenti, amely alkalmas a helyi élelmiszertermelés jellegzetességeinek térbeli megjelenítésére, a jelenlegi kistermelői aktivitási szint és a jövőbeli fejlődési potenciál értékelésére. Az erőforrások optimális elosztása érdekében a biofizikai korlátozó tényezőket jelen elemzésben a mezőgazdasági területek arányával vettük figyelembe. Eredményeink arra utalnak, hogy a kelet-magyarországi régió fejlődési potenciálja a legnagyobb, mert a termelés jelen szintje és a termelési kapacitás egyaránt számottevő. Budapest a jelenlegi termelés szempontjából nem meghatározó, ugyanakkor a kistermelők az átlagosnál sokkal nagyobb arányban integrálódtak a rövid ellátási láncokba, ami a magasabb profit lehetőségét biztosíthatja számukra. Általában véve hazánkra jellemző, hogy a helyiélelmiszer-mozgalom még kezdeti fázisban van. Módszerünk alkalmas a helyi élelmiszerrendszerek szakpolitikai fejlesztésének megalapozására, hiszen kimutatja a fejlődési egyenlőtlenségeket, a fejlesztendő területeket, s ezáltal hozzá tud járulni realisztikus politikai célok kitüzéséhez, valamint az elért eredmények objektív értékeléséhez.

Zsófia BENEDEK: junior research fellow, Institute of Economics, Centre for Economic and Regional Studies, Hungarian Academy of Sciences, Budapest; benedek.zsofia@krtk.mta.hu

Bálint BALÁZS: Environmental Social Science Research Group (ESSRG); junior research fellow, Szent István University, Gödöllő; balazs.balint@essrg.hu

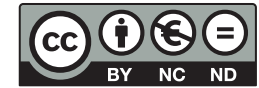


KEYWORDS: relocalisation, local food supply systems, short food supply chains, rural development, quantitative analysis

ABSTRACT: Short food supply chains have been expanding very fast worldwide in the last few years. The political intention of food production relocalisation shows similarly positive tendencies. Data from transitional countries are scarce. This paper aims to bridge the gap by studying patterns and processes of local food systems development in Hungary. Spatial patterns and development potential of local food systems are analysed in the 19 Hungarian counties and the capital, Budapest, in this paper. In order to help policy-making, a quantitative focus is applied, which is a rare approach in analysing food system relocalisation.

This study is based on the Index of Food Production Relocalisation ("élelmiszerrelokalizációs termelöi index", ÉRTI), which is a suitable tool to map the characteristics of local food production and to evaluate the current level of small-scale farming as well as future development potential. The following indicators are considered: the number and ratio of organic farmers, the number and ratio of local food producers advertising in the local food directory, the number and ratio of small-scale producers, the number of certification schemes and the number and ratio of farms producing food for the market. With regard to the optimal allocation of support (funding), the limits of biophysical factors have been taken into account as a measuring stick to define agricultural areas for the purpose of this paper.

Our results show uneven distribution patterns in the counties, and also various indicators of local food production scores which are remarkably different in some cases: The development potential is the highest in the eastern part of Hungary, where the current production level is low. At the moment, production in Budapest is not significant; however, local small-scale farmers are participating in short food supply chains much more than the country average - which allows them to realise higher profits. In general, the "buy-local-food movement" is only in its beginnings in Hungary.

Our method can be used to provide socio-economic baselines for evolving policies that aim at local food systems development as it quantitatively reveals underdeveloped areas or hidden aspects that need further support. Thus, realistic policy goals can be set and results can be monitored and objectively evaluated.

Data availability is the main limiting factor. Future research will include the analysis of background indicators (such as socio-economic characteristics of urban and rural populations, features of tourism, etc.) to understand the current distribution of the local food production potential. In the future we also aim to consider marketing possibilities and the spatial pattern of consumer demand to fully understand the potential of the local food sector development in Hungary.

\section{Bevezetés}

Az elmúlt években gyors fejlődésnek indult rövid ellátási láncok a szakpolitika érdeklődését is felkeltették. A szektor helyzetéről készült legutóbbi európai uniós áttekintés szerint rövid ellátási láncokról akkor beszélhetünk, ha a termelők és fogyasztók közötti közvetítők (leggyakrabban kiskereskedők) száma minimális vagy nulla; az élelmiszer-termelés, -feldolgozás és -kereskedelem földrajzilag körülhatárolt területen történik (Kneafsey, Venn, Schmutz, Balázs, Trenchard, Eyden-Wood, Bos, Sutton, Blackett 2013).

A közpolitikai diskurzus a helyi élelmiszer fogalmának értelmét gyakran az iparszerű, termőhelyhez nem köthető, szezonalitást nélkülöző, globális élelmiszer-hálózatokból származó élelmiszerrel szembeállítva keresi és találja meg. 
Ilyen beállításban a helyi élelmiszer iránti fogyasztói preferencia a globális élelmiszer-ellátással szembeni állampolgári ellenállásként is értelmezhető. Az érintettek oldalán jelentkező előnyök felől nézve a rövid ellátási láncok jelentősége az, hogy a helyi termelők iránti fogyasztói bizalom és a helyi termékek iránti kereslet gazdaságilag lehetővé teszi, hogy a gazdálkodók nagyobb szeletet sajátítsanak el a hozzáadott értékből. Ugyanakkor a rövid ellátási láncok a helyi természeti erőforrások megőrzéséhez, a helyi közösségek ellenálló képességének növeléséhez, a helyi tudás értékének felértékelődéséhez és a helyi hagyományok átörökítéséhez is hozzájárulhatnak (Hendrickson, Heffernan 2002).

A rövid ellátási láncok esetében kevés az empirikus és általánosítható - különösen egy teljes országra kiterjesztett - kvantitatív kutatási eredmény. Keveset tudunk tágabb környezetünk, Kelet-Közép-Európa ez irányú tapasztalatairól. Az átmeneti országok rövid ellátási láncainak fejlődési mintázatai és folyamatai pedig különösen érdekesek lennének, hiszen korántsem könnyen összevethetők a nyugat-európai és amerikai tapasztalatokkal. Magyarországon a domináns tradicionális élelmiszer-ellátási formák (termelői piacok, vásárcsarnokok) erősen függnek a közösségi forrásoktól és beruházásoktól. Az új típusú, neotradicionális formák (dobozrendszerek, webáruházak, közösségi mezőgazdaság, bevásárló körök) megjelenése és sikere jobbára városi és várostérségi körzetekben mutatható ki (Balázs 2012). Az új agrár- és vidékfejlesztési politikának jelentős szerepe van a fenntartható és helyi agrár-élelmiszer rendszerek víziójának megalkotásában, valamint a relokalizáció politikai támogatottságának megteremtésében, város és vidéke közös sorsának elismerésében, termelők és fogyasztók újrakapcsolódását lehetővé tevő szakpolitikai eszközök formálásában. A kis léptékű élelmiszer-előállítóknak, kistermelőknek, családi gazdálkodóknak nyújtott kedvezmények és rugalmassági szabályok különösen sokat segítettek a rövid ellátási láncok felértékelődésében és ugrásszerü elterjesztésében (Balázs 2012). A közös agrárpolitika kettes - vidékfejlesztési - pillérében a rövid ellátási láncok tematikus alprogram a 2014-2020 közötti időszakban további lehetőségeket ad arra, hogy a tagállamok „különös jelentőséggel bíró szükségleteikkel” foglalkozhassanak. Ugyanakkor a politikai támogatottság ellenére a kistermelők száma nem növekszik, az új helyi élelmiszer-minősítési rendszerek (helyi termék védjegyek) ismertsége alacsony, és nem szolgálja a már elismert akkreditációs rendszerek és élelmiszer-biztonsági előírások elterjedését. Mi több, a kereslet nem kimagasló: mindössze minden tizedik fogyasztó vásárol rendszeresen élelmiszert közvetlenül a gazdálkodóktól (Balázs 2012).

Az élelmiszer-ellátás relokalizációja fontos közpolitikai célkitűzéssé vált nemzeti és EU-s szinten egyaránt: a rövid ellátási láncok szakpolitikai eszközként szolgálnak az egészséges táplálkozási szokások elterjesztésében, a környezetkímélő gazdálkodási rendszerek és a rövidebb szállítás miatt a fenntarthatóbb étkezési kultúra terjesztésében; a piacok közösségerősítő erejére építő fenntartható városfejlesztésben (Janssens, Sezer 2013); valamint az endogén vidékfejlesztésben is (Peters 2012). Ugyanakkor a rövid ellátási láncok előnyeiről és lehetőségeiről szóló figye- 
lemre méltó politikai és érdekartikulációs diskurzust nehezíti a szakpolitikai tervezést megfelelően megalapozó, a helyi élelmiszerrendszerek térbeli kiterjedését feltáró kvantitatív kutatási eredmények hiánya.

Cikkünk elméleti célkitűzése, hogy országos szintü kvantitatív elemzéssel kimutassuk, hogy a termelők szempontjából hol tart ma a rövid ellátási láncok fejlődése Magyarországon, és hozzájáruljunk a rövid ellátási láncok társadalmigazdasági hatásairól és térbeni-társadalmi mintázatairól szóló akadémiai diskurzushoz. A jelenlegi térbeli mintázat feltárása mellett módszertani célunk egy bizonyítékalapú szakpolitikai fejlesztés igényeinek megfelelő indikátor fejlesztése, amely képes területileg megjeleníteni az eltérő vidékfejlesztési szükségleteket és lehetőségeket. Munkánk a Ricketts Hein, Ilbery és Kneafsey (2006) által kifejlesztett élelmiszer-relokalizációs indexre épül. E mutató célja, hogy feltárja a helyi élelmiszerrendszerek fejlődésének térbeli elterjedtségét, erősségeit és gyengeségeit. Ezek alapján megállapítható az e rendszerekre irányuló korábbi kutatási eredmények reprezentativitása, és megalapozhatók a későbbi kutatások is. A rövid ellátási láncok erősen kontextusfüggő fejlődése az eltérő földrajzi, társadalmi-gazdasági és kulturális lehetőségek eredménye. Hasonlóképp, az eredeti index összetevői (például a Women's Institute szövetkezeti piacai) az angol és walesi fejlődés sajátságait tükrözik (Ricketts Hein, Watts 2010); emiatt a számunkra elérhető és kulturálisan megfeleltethető összetevők kiválasztásával a hazai helyzetre igyekeztünk alkalmazni az indexet.

Eredményeinkkel a 2014-2020 közötti EU programozási időszak vidékfejlesztési szakpolitikája számára kívánunk állapotfelmérést készíteni, amely megalapozhatja a rövid ellátási láncok fejlesztésének irányát, a támogatások hatékonyabb felhasználását és monitorozását. A mérőszám segítségével értékelhetővé válik a szektorra irányuló beavatkozások, a jogi, intézményes, gazdasági és kommunikációs ösztönzők hatása, kimutatható, hogy mely területeken szükséges szakpolitikai intervenció a rövid ellátási láncok és lehetőség szerint a tágabb régió fejlesztéséhez.

\section{Adatok és módszerek}

A Ricketts Hein, Ilbery és Kneafsey (2006) által kifejlesztett élelmiszer-relokalizációs index eredeti formájában két fö összetevőből, a termelési és értékesítési indexből áll. Jelen írás célja az egyik összetevő, a termelés térbeli mintázatainak feltárása és az élelmiszer-relokalizációs termelői index hazai viszonyokra való adaptálása. Elméleti szinten számtalan indikátor áll rendelkezésre a kis léptékü élelmiszer-előállítók működésének jellemzésére, ezek közül azonban csak néhány alkalmas az egész országra kiterjedő elemzésre, amely mind a 19 megye és Budapest esetében is releváns. Az élelmiszer-relokalizációs termelői index kialakításához öt indikátort használtuk: 
- A biogazdálkodók száma. A Ricketts Hein, Ilbery és Kneafsley (2006) által is használt indikátor hátterében az a felismerés áll, hogy a rövid ellátási lánc és az ökológiai termelés fogalma szorosan összekapcsolódik. Mindkettőre jellemző a környezetkímélő termelési mód, amely kedvez a helyi agrobiodiverzitásnak, és eredeti szándéka szerint mindkettő csökkenteni kívánja a szállítás és a logisztika környezetterhelését, amelynek megfelelő módja a helyben történő értékesítés. Sok biogazdálkodó értékesít rövid ellátási láncokban (például termelői piacon, közösségi mezőgazdaságon keresztül vagy dobozrendszerben) (Benedek, Fertő 2014); illetve sok rövid ellátási láncban levő gazdálkodó termel ökológiai módon (sokszor azonban tanúsítás nélkül) (Higgins, Dibden, Cocklin 2008; Jarosz 2008). Az adatokat a két hazai minősítő szervezet (Biokontroll Hungária Nonprofit Kft. - HU-ÖKO-01 - és Hungária ÖkoGarancia Kft. - HU-ÖKO-02) honlapjáról gyűijtöttük, és ezek a 2013. augusztusi állapotot mutatják be.

- Helyiélelmiszer-adatbázisban hirdető helyi termelók száma. A helyitermékadatbázisok száma folyamatosan nő, többnyire vidékfejlesztéssel foglalkozó civil kezdeményezések áldozatos munkájának eredményeképpen. Az országos lefedettségü adatbázisok száma azonban jóval alacsonyabb. Jelen kutatásban a legnagyobb, a gazdálkodóknak ingyenes regisztrációt biztosító, csaknem 12500 gazdálkodó adatait tartalmazó Termelőtől.hu Kft. honlapot használjuk (az adatok 2013 augusztusára vonatkoznak). Mivel a rövid ellátási láncok nagymértékben támaszkodnak a közösségi médiára, ezért ez az indikátor azt ragadja meg, hogy a gazdák mennyiben hajlandók és képesek használni az egyre bővülő online megjelenési lehetőségeket.

- A kistermelók száma. A legnagyobb arányban a kis léptékủ élelmiszer-előállítók vesznek részt a rövid ellátási láncokban - már csak azért is, mert ők azok, akik a kis volumen miatt nem tudják kihasználni a méretgazdaságosságból adódó lehetőségeket, ezért kiszorulnak a globális versenyből. Az elemzésben az Országos Területfejlesztési és Területrendezési Információs Rendszer (TeIR) legfrissebb, 2011-re vonatkozó adatait használjuk.

- A védjegyek száma. A rövid ellátási láncokhoz kapcsolódóan a védjegyek feladata, hogy lehetővé tegyék a helyben készült termékek megkülönböztetését. Néhány szerző a rövid ellátási láncok esetében vitatja a védjegyek létjogosultságát azon az alapon, hogy ha egy terméknek szüksége van megkülönböztetésre, akkor az (vagy a termelö) nem integrálódott a helyi társadalmi-gazdasági környezetbe (Watts, Ilbery, Maye 2005). Vannak azonban, akik szerint a fogyasztók szívesebben vásárolják meg ezeket a termékeket saját helyi identitásuk hangsúlyozása, megerősítése érdekében (Chambers, Lobb, Butler, Harvey, Traill 2007; Winter 2003). Kneafsey és munkatársai (2013), összefoglalva a védjegyek előnyeit és hátrányait rámutatnak arra, hogy a túl sok védjegy ahelyett, hogy segítené, inkább csak összezavarja a fogyasztókat. Ezzel együtt fontosnak tartjuk a védjegyek számát mutató indikátor használatát, mivel képes 
megragadni a gazdálkodói nyitottságot a helyi élelmiszer-eloállítási hagyományok, értékek megőrzésére, hangsúlyozására és a rövid ellátási láncokban történő részvételre. Mutatja továbbá a civil szféra aktivitási szintjét a helyi élelmiszerrendszerek előmozdításában, hiszen a helyi termék védjegyek bejegyezését jellemző módon civil kezdeményezések végzik. A Szellemi Tulajdon Nemzeti Hivatala honlapjáról származó, 2013 augusztusára vonatkozó adatainkból azokat az élelmiszerrel kapcsolatos védjegyeket vettük bele az elemzésbe, amelyek nevében szerepel a „helyi” megnevezés, és nem magánszemélyek vagy viszonteladók a védjegyjogosultak. Az országos védjegyeket (pl. amelyek országos lefedettségủ szervezetekhez köthetők) kizártuk az elemzésből, annak érdekében, hogy biztosíthassuk a helyi jelleget.

- Értékesitésre termelo" egyéni gazdaságok száma. Az indikátorral ki lehet szűrni az elsősorban önellátásra termelő gazdaságokat. Az általános mezőgazdasági összeírás (ÁMÖ) 2010-re vonatkozó adatait használtuk.

A rövid ellátási láncok kínálati oldalát jelentő kistermelői élelmiszer-termelés és -értékesítés a fent ismertetett indikátorokkal különböző aspektusokból vizsgálható. Bár önmagában egyik mutató sem képes az élelmiszer-relokalizáció termelői feltételeinek komplex megjelenítésére, több mutató kombinációjával az általános trendek kirajzolódnak. Az elemzésben nem abszolút számokat veszünk figyelembe (az egyes mutatók nagyságrendjei különböznek, így ennek nem is lenne sok értelme), hanem a megyék rangsorát képezzük. Az adott mutató mentén a legmagasabb értékkel rendelkező megye rangja 1 (ez határozza meg az egyes megyék relatív fejlettségét a többi megyéhez viszonyítva). Az élelmiszer-relokalizációs termelői indexet a következők szerint képezzük:

$$
\text { ÉRTI } I_{j i}=100 \frac{R_{i}}{N M},
$$

ahol ÉRTI ${ }_{j i}$ az i. megye jelen termelési aktivitásra vonatkozó élelmiszer-relokalizációs termelői indexe, $R_{i}$ az egyes indikátorok rangszámainak összege $i$. megyében, $N$ az egyedi változók száma (5), M a megyék száma (20). Az index elvi szélsőértékei: 5 (ha egy megye minden változó esetében első) és 100 (ha egy megye minden változó esetében 20.). Az alacsonyabb érték azt jelenti, hogy a termelés jelenlegi szintje alapján nagyobb az adott megye részvétele a helyiélelmiszer-mozgalomban: több a helyi élelmiszerrendszerben potenciálisan részt vevő kistermelö, őstermelö, civil kezdeményezés, azaz fejlettebb a „kínálati oldal”.

A fent bemutatott indikátorok megragadják a kis léptékủ élelmiszer-elóállítói tevékenység néhány, a támogatáspolitika szempontjából is fontos jellegzetességét és annak térbeli elterjedtségét, de önmagában nem elegendők a relokalizációs potenciál kifejezésére. A rövid ellátási láncokban ugyanis a nagyobb profitot realizáló gazdák mintája, pozitív tapasztalatainak megosztása (a „szájreklám”) is jelentősen hozzájárul az elterjedéshez. Minél jellemzőbb a rövid ellátási láncokban való részvétel az adott területen egy adott időpontban, annál gyorsabb terjedés (és sikeresebb támogatáspolitika) valószínüsíthető a 
következő időszakban, annál nagyobb a fejlődési potenciál. Mindez természetesen csak a piac telítődéséig érvényes, amíg minden fogyasztói igényt sikerült helyben termelt élelmiszerrel kielégíteni. A magyarországi helyiélelmiszer-mozgalom azonban még a kezdeti fázisban van, telítődés a közeljövőben nem várható.

A fejlődési potenciál megjelenítésére számszerüsítjük a helyi élelmiszertermelés relatív helyzetét is. A korábban bemutatott indikátorok értékeit a társas és egyéni gazdaságok számához (ÁMÖ, 2010) viszonyítjuk. Ez alól egyedül a védjegyek száma kivétel, amely erősebben kötődik a helyi civil szervezetek aktivitási szintjéhez, mint a helyi gazdaságok számához. Az így definiálható ÉRTI mutató a helyi élelmiszerrendszerek (fejlődési) potenciálját számszerűsíti $i$. megyében, és a következő indikátorokból tevődik össze: a biogazdálkodók aránya az összes gazdasághoz képest, a helyiélelmiszer-adatbázisban hirdető helyi termelők aránya, a kistermelők aránya, a védjegyek száma, az értékesítésre termelő egyéni gazdaságok aránya.

A két mutatót összehasonlítjuk egymással és a mezőgazdasági területek arányával (az adatok forrása a Központi Statisztikai Hivatal). Az összehasonlítást Pearson-korrelációval végezzük (a normáleloszlás tesztelésére a Shapiro-Wilk-, a Shapiro-Francia- és a Kurtosis-teszteket használjuk), illetve becsüljük a Spearman-féle rangkorreláció értékét is.

A mezőgazdasági területek aránya mutatója alkalmas arra is, hogy kifejezzük a lokális termőhelyi adottságokat mint biofizikai korlátozó tényezőket. Annak érdekében, hogy ugyanolyan skálán kapjuk meg az eredményeket, mint az ÉRTI-mutatók esetében (amelyeknél az alacsonyabb érték jobb teljesítmény jelez), a nem mezőgazdasági területek arányát (NMTA $)$ használjuk a számításokban.

A támogatáspolitika szempontjából (tekintettel a helyi élelmiszerrendszerek általános alacsony fejlettségi fokára) abban a megyében érdemes koncentrálni az erőforrásokat, ahol a relokalizáció feltételei már adottak: jelen van a termelési potenciál mind humán, mind biofizikai alapja, és az intézkedés várhatóan a legnagyobb hatásfokú lehet (leggyorsabban lehet eredményeket elérni). Ennek alapján akkor tekintjük optimálisnak az erőforrás-felhasználást, ha az a lehető legnagyobb számszerüsíthető eredményt, hatást (a helyi élelmiszerrendszerben részt vevő kis léptékű gazdálkodók számának növekedését) a lehető legrövidebb idő alatt éri el. Mindezek figyelembevételével az optimális allokáció $(O A)$ mutatóját a következők szerint számítjuk:

$$
O A_{i}=E R T I_{j i}+E R T I_{p i}+N M T A_{i}
$$

Minél alacsonyabb az $O A$ értéke, annál inkább az adott megyében érdemes koncentrálni az erőforrásokat, mivel a rövid ellátási láncokban potenciálisan részt vevő kis léptékủ élelmiszertermelők megfelelő számban jelen vannak, illetve arányaiban is elég sokan vannak ahhoz, hogy a pozitív változások viszonylag gyorsan továbbterjedhessenek, továbbá a terület biofizikai kapacitásai is megfelelőek a termelés biztosításához. 


\section{Az eredmények értékelése}

Az 1. táblázat az ÉRTI értékeit mutatja be, vagyis a kistermelők jelen aktivitási szintjét számszerüsíti, az 1. ábra pedig a megyei értékeket mutatja be térképen.

A kistermelői élelmiszer-termelés jelen aktivitási szintjét jelző indikátorok feltűnően különböző eredményeket adnak, ami azt jelzi, hogy a fejlődés a mutatók által lefedett dimenziókban nem konzisztens. Például Bács-Kiskun megye a legtöbb mutató alapján igen fejlettnek tekinthető a többi megyéhez viszonyítva, vagyis a helyi élelmiszertermelés erős bázissal rendelkezik, ugyanakkor a gazdálkodók nem használják ki az üzleti világban ma már fősodorba került közösségi média által nyújtott lehetőségeket. Ilyen módon az ÉRTI kiválóan al-

1. táblázat: A kistermelők jelenlegi megyei aktivitási szintje (ÉRTI.)

The current activity level of small-scale farmers in Hungarian counties

\begin{tabular}{|c|c|c|c|c|c|c|c|c|c|c|c|}
\hline \multirow[t]{2}{*}{ Megye } & \multicolumn{2}{|c|}{$\begin{array}{l}\text { A biogazdál- } \\
\text { kodók száma }\end{array}$} & \multicolumn{2}{|c|}{$\begin{array}{c}\text { A helyi- } \\
\text { élelmiszer- } \\
\text { adatbázisban } \\
\text { hirdető helyi } \\
\text { termelők száma² }\end{array}$} & \multicolumn{2}{|c|}{$\begin{array}{c}\text { A } \\
\text { kistermelök } \\
\text { száma }\end{array}$} & \multicolumn{2}{|c|}{$\begin{array}{c}\text { A } \\
\text { védjegyek } \\
\text { száma }\end{array}$} & \multicolumn{2}{|c|}{$\begin{array}{c}\text { Értékesítésre } \\
\text { termelo” } \\
\text { egyéni } \\
\text { gazdaságok } \\
\text { száma } \\
\end{array}$} & \multirow[t]{2}{*}{$\overline{E R T I_{j}}$} \\
\hline & Érték & Rang & Érték & Rang & Érték & Rang & Érték & Rang & Érték & Rang & \\
\hline Szabolcs-Szatmár-Bereg & 146 & 1 & 934 & 5 & 864 & 5 & 2 & 7 & 5082 & 9 & 27,0 \\
\hline Bács-Kiskun & 119 & 2 & 122 & 20 & 1847 & 2 & 4 & 2 & 13442 & 2 & 28,0 \\
\hline Hajdú-Bihar & 112 & 3 & 542 & 12 & 1080 & 3 & 1 & 9 & 9444 & 3 & 30,0 \\
\hline Pest & 81 & 6 & 822 & 7 & 598 & 9 & 4 & 2 & 5464 & 7 & 31,0 \\
\hline Jász-Nagykun-Szolnok & 72 & 9 & 654 & 10 & 772 & 6 & 2 & 7 & 19269 & 1 & 33,0 \\
\hline Csongrád & 49 & 10 & 374 & 15 & 947 & 4 & 5 & 1 & 7651 & 5 & 35,0 \\
\hline Győr-Moson-Sopron & 89 & 4 & 486 & 13 & 564 & 10 & 1 & 9 & 4175 & 11 & 47,0 \\
\hline Borsod-Abaúj-Zemplén & 87 & 5 & 290 & 16 & 355 & 14 & 3 & 4 & 5375 & 8 & 47,0 \\
\hline Békés & 80 & 8 & 234 & 17 & 2130 & 1 & 0 & 17 & 9235 & 4 & 47,0 \\
\hline Tolna & 29 & 16 & 990 & 4 & 732 & 7 & 1 & 9 & 3079 & 12 & 48,0 \\
\hline Zala & 25 & 19 & 1158 & 1 & 332 & 15 & 3 & 4 & 2644 & 13 & 52,0 \\
\hline Heves & 32 & 13 & 598 & 11 & 386 & 13 & 1 & 9 & 5937 & 6 & 52,0 \\
\hline Veszprém & 35 & 12 & 1102 & 2 & 267 & 17 & 1 & 9 & 2103 & 17 & 57,0 \\
\hline Baranya & 40 & 11 & 178 & 18 & 536 & 11 & 3 & 4 & 2346 & 15 & 59,0 \\
\hline Somogy & 31 & 15 & 878 & 6 & 518 & 12 & 0 & 17 & 4972 & 10 & 60,0 \\
\hline Vas & 26 & 18 & 1046 & 3 & 274 & 16 & 1 & 9 & 2148 & 16 & 62,0 \\
\hline Fejér & 32 & 13 & 430 & 14 & 626 & 8 & 0 & 17 & 2608 & 14 & 66,0 \\
\hline Budapest & 81 & 6 & 166 & 19 & 227 & 18 & 1 & 9 & 345 & 20 & 72,0 \\
\hline Nógrád & 28 & 17 & 766 & 8 & 71 & 20 & 1 & 9 & 1132 & 18 & 72,0 \\
\hline Komárom-Esztergom & 24 & 20 & 710 & 9 & 212 & 19 & 0 & 17 & 1005 & 19 & 84,0 \\
\hline Összesen & 1218 & - & 12480 & - & 13338 & - & 34 & - & 107456 & - & - \\
\hline
\end{tabular}

Forrás: 1: HU-ÖKO-01 és HU-ÖKO-02 (2013); 2: Termelőtól.hu Kft (2013); 3: TeIR (2011); 4: SZTNH (2013); 5: ÁMÖ (2010) alapján saját szerkesztés. 
1. ábra: A kistermelők jelenlegi megyei aktivitási szintje (ÉRTI.) The current activity level of small-scale farmers in Hungarian counties

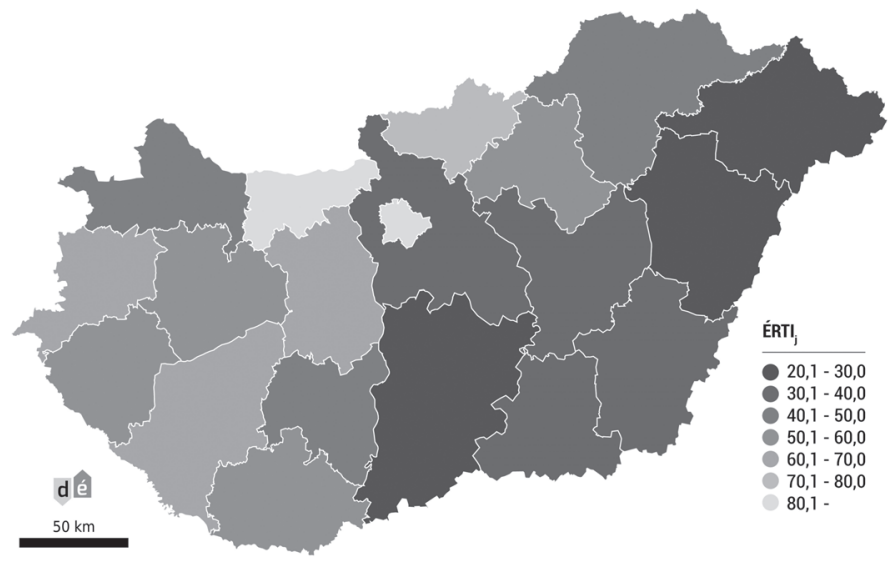

kalmas arra, hogy rámutasson az inkonzisztens fejlődésre, vagyis objektív mércével segítheti realisztikus szakpolitikai célok megfogalmazását.

A gazdaságilag legfejlettebb Budapest a legtöbb mutató szempontjából, vagyis konzisztens módon közepes vagy alacsony aktivitást mutat. A keleti országrészekben (elsősorban Szabolcs-Szatmár-Bereg és Hajdú-Bihar megyében) viszonylag erős a kistermelői jelenlét, ami a további fejlődés szempontjából kiváló bázist jelent. A tapasztalt mintázat gyengén ugyan, de korrelál a mezőgazdasági területek arányával (illetve rangsorával), amit a 2. ábra mutat be $\left(R^{2}=0,2686 ; p=0,0192\right.$; a normáleloszlás-próbák eredményeit a 2 . táblázat ismerteti; a Spearman-féle $\rho=-0,5456 ; p=0,0128$ ).

2. ábra: A mezőgazdasági területek aránya a megyékben The ratio of agricultural areas in Hungarian counties

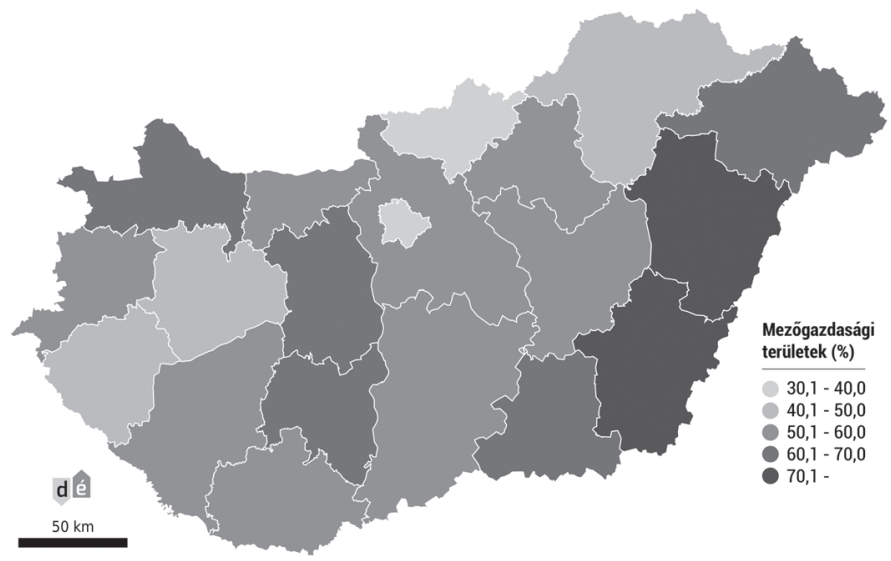

Adatok forrása: KSH. 
2. táblázat: A normáleloszlás-tesztek eredménye

Test results for normal distribution

\begin{tabular}{lccc}
\hline & ÉRTI & ÉRTI & $\begin{array}{c}\text { Mezőgazdasági területek } \\
\text { aránya }\end{array}$ \\
\hline Shapiro-Wilk p érték & & 0,9620 & 0,9700 \\
Shapiro-Francia p érték & 0,4903 & 0,9518 & 0,9912 \\
Kurtosis-teszt p érték & 0,6369 & 0,7016 & 0,9178 \\
\hline
\end{tabular}

A 3. táblázat és a 3. ábra a helyi élelmiszertermelés relatív mutatóit és a helyi élelmiszerrendszerek fejlődési potenciálját mutatja be (ÉRTI), vagyis azt, hogy a támogatáspolitika a várakozások szerint milyen hamar érné el a célját. A mutatókat a társas és egyéni gazdaságok számához viszonyítva számítottuk ki.

3. táblázat: A helyi élelmiszerrendszerek megyei szintű fejlődési potenciálja (ÉRTI ) Development potential of local food systems in Hungarian counties

\begin{tabular}{|c|c|c|c|c|c|c|c|c|c|c|c|}
\hline \multirow[t]{2}{*}{ Megye } & \multicolumn{2}{|c|}{$\begin{array}{c}\text { A biogazdál- } \\
\text { kodók } \\
\text { aránya }^{1}\end{array}$} & \multicolumn{2}{|c|}{$\begin{array}{c}\text { A helyi- } \\
\text { élelmiszer- } \\
\text { adatbázisban } \\
\text { hirdető helyi } \\
\text { termelók } \\
\text { aránya }^{2}\end{array}$} & \multicolumn{2}{|c|}{$\begin{array}{c}\text { A } \\
\text { kistermelők } \\
\text { aránya }^{3}\end{array}$} & \multicolumn{2}{|c|}{$\begin{array}{c}\text { A védjegyek } \\
\text { száma }\end{array}$} & \multicolumn{2}{|c|}{$\begin{array}{c}\text { Értékesítésre } \\
\text { termelő egyéni } \\
\text { gazdaságok } \\
\text { aránya }^{5}\end{array}$} & \multirow[t]{2}{*}{$E ́ R T I_{p}$} \\
\hline & Érték & Rang & Érték & Rang & Érték & Rang & Érték & Rang & Érték & Rang & \\
\hline Budapest & 5,19 & 1 & 10,64 & 1 & 14,55 & 1 & 1 & 9 & 22,12 & 7 & 19,0 \\
\hline Szabolcs-Szatmár-Bereg & 0,55 & 2 & 3,54 & 8 & 3,27 & 5 & 2 & 7 & 19,24 & 9 & 31,0 \\
\hline Győr-Moson-Sopron & 0,50 & 3 & 2,73 & 10 & 3,17 & 6 & 1 & 9 & 23,46 & 6 & 34,0 \\
\hline Bács-Kiskun & 0,22 & 7 & 0,22 & 20 & 3,39 & 4 & 4 & 2 & 24,66 & 4 & 37,0 \\
\hline Heves & 0,18 & 12 & 3,36 & 9 & 2,17 & 11 & 1 & 9 & 33,34 & 1 & 42,0 \\
\hline Csongrád & 0,15 & 14 & 1,16 & 15 & 2,94 & 7 & 5 & 1 & 23,76 & 5 & 42,0 \\
\hline Tolna & 0,14 & 16 & 4,88 & 6 & 3,61 & 3 & 1 & 9 & 15,16 & 10 & 44,0 \\
\hline Hajdú-Bihar & 0,24 & 5 & 1,18 & 14 & 2,36 & 10 & 1 & 9 & 20,64 & 8 & 46,0 \\
\hline Békés & 0,21 & 8 & 0,63 & 19 & 5,71 & 2 & 0 & 17 & 24,77 & 3 & 49,0 \\
\hline Veszprém & 0,20 & 9 & 6,36 & 4 & 1,54 & 15 & 1 & 9 & 12,14 & 13 & 50,0 \\
\hline Nógrád & 0,26 & 4 & 7,11 & 2 & 0,66 & 20 & 1 & 9 & 10,50 & 18 & 53,0 \\
\hline Vas & 0,15 & 15 & 6,07 & 5 & 1,59 & 13 & 1 & 9 & 12,46 & 12 & 54,0 \\
\hline Baranya & 0,19 & 11 & 0,84 & 17 & 2,53 & 9 & 3 & 4 & 11,08 & 16 & 57,0 \\
\hline Komárom-Esztergom & 0,22 & 6 & 6,57 & 3 & 1,96 & 12 & 0 & 17 & 9,31 & 20 & 58,0 \\
\hline Pest & 0,17 & 13 & 1,77 & 13 & 1,29 & 16 & 4 & 2 & 11,79 & 15 & 59,0 \\
\hline Jász-Nagykun-Szolnok & 0,10 & 18 & 0,92 & 16 & 1,08 & 18 & 2 & 7 & 26,96 & 2 & 61,0 \\
\hline Borsod-Abaúj-Zemplén & 0,20 & 10 & 0,65 & 18 & 0,80 & 19 & 3 & 4 & 12,12 & 14 & 65,0 \\
\hline Zala & 0,10 & 19 & 4,45 & 7 & 1,28 & 17 & 3 & 4 & 10,17 & 19 & 66,0 \\
\hline Fejér & 0,13 & 17 & 1,80 & 12 & 2,63 & 8 & 0 & 17 & 10,95 & 17 & 71,0 \\
\hline Somogy & 0,09 & 20 & 2,65 & 11 & 1,56 & 14 & 0 & 17 & 15,00 & 11 & 73,0 \\
\hline Összesen & - & - & - & - & - & - & 34 & - & - & - & - \\
\hline
\end{tabular}

Forrás: 1: HU-ÖKO-01 és HU-ÖKO-02 (2013); 2: Termelötól.hu Kft (2013); 3: TeIR (2011); 4: SZTNH (2013); 5: ÁMÖ (2010), valamint ÁMÖ (2010) (társas és egyéni gazdaságok száma) alapján saját szerkesztés. 
3. ábra: A kistermelői élelmiszer-termelés megyei fejlődési potenciálja (ÉRTI $)$ Development potential of local food systems in Hungarian counties

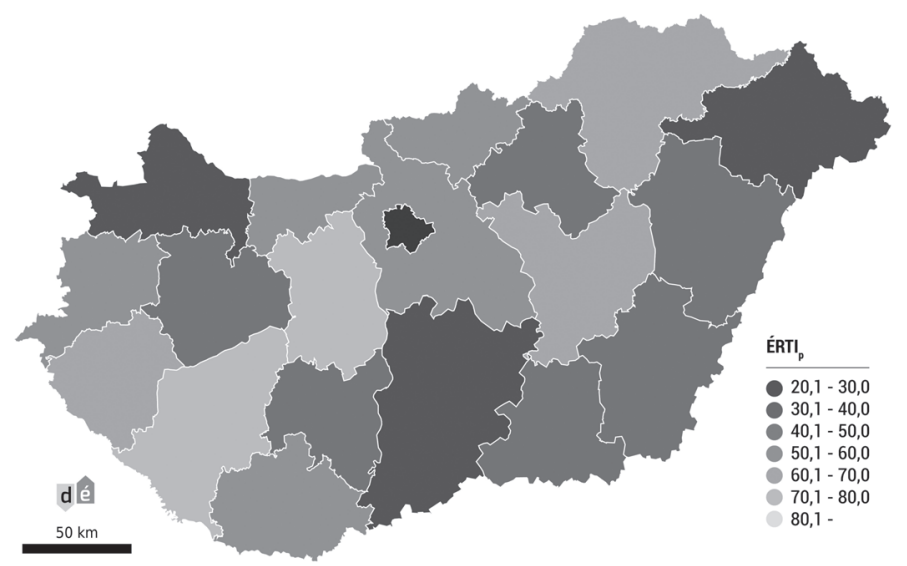

Az ÉRTI mutatóval kapott eredményekhez hasonlóan az ÉRTI ${ }_{p}$ számításához használt indikátorok is inkonzisztensek, belső egyenlőtlenségeket takarnak. Például Jász-Nagykun-Szolnok megyében az értékesítésre termelő egyéni gazdaságok aránya viszonylag magas, e gazdaságok ugyanakkor a jelek szerint nem használják ki maradéktalanul a rövid ellátási láncok nyújtotta lehetőségeket. Arányaiban a legtöbb gazdálkodó Budapesten vesz részt a kis léptékủ élelmiszertermelésben (ahol egyébként a kistermelők abszolút száma meglehetősen alacsony). Az ÉRTI mutatói összességében megerősítették azon feltevésünket, hogy a helyi élelmiszertermelés egyelőre viszonylag alacsony fokú hazánkban, így a mozgalom további térnyerése valószínűsíthető a jövőben.

A 4. táblázat bemutatja a helyi élelmiszertermelés jelen helyzetét és fejlödési potenciálját, valamint a nem mezőgazdasági területek arányát. E mutatók kombinálásával megállapítható, hogy mely területekre érdemes csoportosítani az erőforrásokat annak érdekében, hogy a helyi élelmiszertermelés lehető legnagyobb arányú fejlődését lehessen elérni a lehető legrövidebb idő alatt.

A táblázat alapján számos érdekes megállapítást tehetünk. Először is, az ÉRTI és az ÉRTI ${ }_{p}$, vagyis a jelenlegi helyzet és a jövőbeli fejlődési potenciák között nem áll fenn korrelációs kapcsolat. A fejlődés üteme várhatóan Kelet-Magyarországon (elsősorban Szabolcs-Szatmár-Bereg megyében) lenne a leggyorsabb, a megye az aktuális állapot és a kapacitások alapján is elöl végzett a különböző rangsorokban. Ugyanakkor inkonzisztenciát mutat az ÉRTI ${ }_{j}$ és az ÉRTI alapján felállított rangsorban Budapest, Fejér, Jász-Nagykun-Szolnok vagy Pest megye. A belső ellentmondások feloldása fontos lépés lenne a rövid ellátási láncok hatékony fejlesztése során, és fontos tanulság, hogy a szakpolitikai célkitűzések mellett az eléréshez szükséges időtáv gondos felmérése is szükséges.

A realisztikus célok megfogalmazásához a biofizikai korlátozó tényezőket is érdemes figyelembe venni. A mezőgazdasági termelés számára rendelkezésre 
4. táblázat: A támogatások optimális allokációja $(\mathrm{OA})$ a megyei szinten Optimal allocation of funds

\begin{tabular}{|c|c|c|c|c|c|c|c|c|}
\hline \multirow[t]{2}{*}{ Megye } & \multicolumn{2}{|c|}{$E ́ R T I_{j}$} & \multicolumn{2}{|c|}{$E ́ R T I_{p}$} & \multicolumn{2}{|c|}{ NMTA } & \multicolumn{2}{|c|}{$O A$} \\
\hline & Érték & Rang & Érték & Rang & Érték & Rang & Érték & Rang \\
\hline Szabolcs-Szatmár-Bereg & 27,0 & 1 & 31,0 & 2 & 35,5 & 5 & 93,5 & 1 \\
\hline Hajdú-Bihar & 30,0 & 3 & 46,0 & 8 & 27,7 & 2 & 103,7 & 2 \\
\hline Bács-Kiskun & 28,0 & 2 & 37,0 & 4 & 40,7 & 8 & 105,7 & 3 \\
\hline Csongrád & 35,0 & 6 & 42,0 & 5 & 34,2 & 4 & 111,2 & 4 \\
\hline Békés & 47,0 & 9 & 49,0 & 9 & 23,1 & 1 & 119,1 & 5 \\
\hline Győr-Moson-Sopron & 47,0 & 7 & 34,0 & 3 & 38,7 & 7 & 119,7 & 6 \\
\hline Tolna & 48,0 & 10 & 44,0 & 7 & 30,8 & 3 & 122,8 & 7 \\
\hline Jász-Nagykun-Szolnok & 33,0 & 5 & 61,0 & 16 & 41,5 & 10 & 135,5 & 8 \\
\hline Pest & 31,0 & 4 & 59,0 & 15 & 46,9 & 12 & 136,9 & 9 \\
\hline Heves & 52,0 & 12 & 42,0 & 6 & 47,1 & 13 & 141,1 & 10 \\
\hline Budapest & 72,0 & 18 & 19,0 & 1 & 62,5 & 19 & 153,5 & 11 \\
\hline Baranya & 59,0 & 14 & 57,0 & 13 & 41,1 & 9 & 157,1 & 12 \\
\hline Veszprém & 57,0 & 13 & 50,0 & 10 & 56,2 & 17 & 163,2 & 13 \\
\hline Vas & 62,0 & 16 & 54,0 & 12 & 48,5 & 14 & 164,5 & 14 \\
\hline Borsod-Abaúj-Zemplén & 47,0 & 8 & 65,0 & 17 & 53,9 & 16 & 165,9 & 15 \\
\hline Fejér & 66,0 & 17 & 71,0 & 19 & 38,2 & 6 & 175,2 & 16 \\
\hline Zala & 52,0 & 11 & 66,0 & 18 & 57,6 & 18 & 175,6 & 17 \\
\hline Somogy & 60,0 & 15 & 73,0 & 20 & 48,8 & 15 & 181,8 & 18 \\
\hline Komárom-Esztergom & 84,0 & 20 & 58,0 & 14 & 45,3 & 11 & 187,3 & 19 \\
\hline Nógrád & 72,0 & 19 & 53,0 & 11 & 64,1 & 20 & 189,1 & 20 \\
\hline Pearson-korreláció p érték & & & 3660 & & - & & - & \\
\hline Spearman-féle rangkorreláció p érték & & & 1888 & & & & & \\
\hline
\end{tabular}

álló területek aránya további közvetett módon is hat, mivel kismértékben befolyásolja a kis léptékű termelés jelen aktivitási szintjét. Elemzési módszerünk e biofizikai potenciálok kihasználásában mutatkozó egyenlőtlenségek kimutatására szintén alkalmas. Például az országos átlag (57\%) körüli értékkel jellemezhető Komárom-Esztergom megyében nagyon alacsony a kis léptékű termelők száma, ami komoly korlátozó tényező lehet a rövid ellátási láncok gyors fejlesztése során.

\section{Következtetések}

Írásunk újszerűsége három szempontból ragadható meg. Elsőként a rövid élelmiszerláncokról szóló egyre kiterjedtebb tudományos szakirodalomhoz igyekeztünk hozzájárulni egy kvantitatív elemzéssel. Meggyőződésünk, hogy bizonyítékalapú szakpolitikára és valódi megalapozott tudásra van szüksége e szektor szereplőinek ahhoz, hogy sikeresen tudjanak megfelelni annak a méltányos érdeklődésnek és felfokozott várakozásnak, amely jelenleg is kíséri e szek- 
tor fejlődésének lehetséges irányait. Másodszor, nagy szükségét látjuk olyan indikátorok fejlesztésének, amelyekkel a rövid élelmiszerláncok valós társadalmigazdasági hatásai és a kis léptékủ élelmiszer-előállítás jelenlegi térbeni-társadalmi mintázatai kimutathatóak. Harmadszor, olyan módszertani fejlesztés volt a célunk, amely bizonyítékalapú szakpolitikai fejlesztés kiindulópontjává válhat a 2014-2020 közötti programozási időszakban és egyértelmű szakpolitikai üzeneteket fogalmazhat meg arról, hol lehet a legnagyobb eredményt elérni a szakpolitikai (jogi, intézményi, gazdasági és kommunikációs) ösztönzőkkel.

Az index alkalmazása során számos kihívással szembesültünk. Míg egyes esetekben lehetséges volt az angol eredetihez hasonló indikátort keresni vagy készíteni, néhány esetben nem sikerült a kulturálisan megfelelő indikátor megtalálása. $\mathrm{Az}$ adatok elérhetősége számos ponton korlátozta kutatói lehetőségeinket. Ezzel együtt is úgy látjuk, hogy fenti céljainkhoz az index kitűnően illeszkedik, és értékes eszközévé válhat a helyi élelmiszerrel összefüggő tevékenységek érintettek körében történő értékelésének és hatékonyabb szakpolitikai támogatásának.

Jelen közlemény egy komplex kutatás első lépéséről számol be. Kézenfekvő folytatás olyan háttérváltozók elemzése (városi és vidéki közösségek társadalmigazdasági jellegzetességei, a turizmus, a marketing lehetőségei, a fogyasztói igények térbeli eloszlása stb.), amelyekkel tovább vizsgálható a helyi élelmiszerszektor fejlődésének potenciálja. E gazdasági, jövedelmi, szociológiai, fogyasztási adatok elemzése nélkül a jelenleg bemutatott eredmények önmagukban a jövőbeli szakpolitikák tervezéséhez, EU-s támogatások térbeli elosztásához csalóka trendeket rajzolhatnak.

\section{Köszönetnyilvánítás}

A szerzők köszönettel tartoznak Juhász Anikónak és Rönky Balázsnak az adatbázis összeállításához nyújtott segítségükért. Benedek Zsófia kutatásait az OTKA PD 109177 számú pályázata támogatta. Balázs Bálint kutatásait a Kutató Kari Kiválósági Támogatás - Research Centre of Excellence - 85265/2014/TUDPOL is támogatta. A cikk elkészítésében köszönettel tartozunk a Környezeti Társadalomkutatók (ESSRG) csapatának, akik sokat segítettek a szöveg végleges formájának elkészítésében.

\section{Jegyzet}

1 Felmerülhet kérdésként, hogy mi indokolja a tagok összeadását más matematikai művelet alkalmazása (pl. szorzás) helyett. Mivel a jelen tanulmányban nem az abszolút értékek, hanem a rangsorok fontosak, ezért nincs jelentősége annak, hogy a tényezőket összeadjuk vagy összeszorozzuk. Elvégezve a két műveletet azt tapasztaljuk, hogy a megyék sorrendje csak a rangsor közepén elhelyezkedő megyék esetében változik minimálisan. 


\section{Irodalom}

Balázs B. (2012): Local food system development in Hungary. International Journal of Sociology of Agriculture and Food, 3., 403-421.

Benedek Zs., Fertő I. (2014): Fejlődési lehetőség előtt a biotermelők. A Falu, 2., 9-21.

Chambers, S., Lobb, A., Butler, L., Harvey, K., Traill, W. B. (2007): Local, national and imported foods: a qualitative study. Appetite, 1., 208-213.

Hendrickson, M. K., Heffernan, W. D. (2002): Opening spaces through relocalization: locating potential resistance in the weaknesses of the global food system. Sociologia Ruralis, 4., 347-369.

Higgins, V., Dibden, J., Cocklin, C. (2008): Building alternative agri-food networks: Certification, embeddedness and agri-environmental governance. Journal of Rural Studies, 1., 15-27.

Janssens, F., Sezer, C. (2013): Marketplaces as an urban development strategy. Built Environment, 2., 169-171.

Jarosz, L. (2008): The city in the country: Growing alternative food networks in metropolitan areas. Journal of Rural Studies, 3., 231-244.

Kneafsey, M., Venn, L., Schmutz, U., Balázs, B., Trenchard, L., Eyden-Wood, T., Bos, E., Sutton, G., Blackett, M. (2013): Short food supply chains and local food systems in the EU. A state of play of their socio-economic characteristics. Joint Research Centre Institute for Prospective Technological Studies, European Commission, Brussels

Peters, R. (ed.) (2012): Local food and short supply chains. European Network for Rural Development, Brussels (EU Rural Review; 12.)

Ricketts Hein, J., Ilbery, B., Kneafsey, M. (2006): Distribution of local food activity in England and Wales: an index of food relocalization. Regional Studies, 3., 289-301.

Ricketts Hein, J., Watts, D. (2010): Local food activity in the Republic of Ireland and Great Britain. Irish Geography, 2., 135-147.

Watts, D. C., Ilbery, B., Maye, D. (2005): Making reconnections in agro-food geography: alternative systems of food provision. Progress in Human Geography, 1., 22-40.

Winter, M. (2003): Embeddedness, the new food economy and defensive localism. Journal of Rural Studies, 1., 23-32. 